\title{
PENGEMBANGAN BAHAN AJAR KAJIAN APRESIASI PROSA FIKSI BERBASIS KEARIFAN LOKAL TERINTEGRASI MOBILE LEARNING
}

\author{
Haslinda \\ Pendidikan Bahasa dan Sastra Indonesia, FKIP Universitas Muhammadiyah Makassar \\ Haslinda106@yahoo.co.id
}

\begin{abstract}
Abstrak
Tujuan penelitian ini menciptakan bahan ajar kajian prosa fiksi berbasis kearifan lokal Makassar terintegrasi mobile learning yang layak atau valid, keterbacaan, praktis, dan efektif bagi mahasiswa Program Studi Pendidikan Bahasa dan Sastra Indonesia di Universitas Muhammadiyah Makassar. Jenis penelitian ini adalah penelitian dan pengembangan atau Research and Development (R\&D) dengan menggunakan model ADDIE (Analyze, Design, Develop, Implement, Evaluation). Teknik analisis data menggunakan teknik analisis deskriptif kualitatif dan statistik deskriptif. Dalam penelitian ini ditemukan bahan ajar yang layak atau valid ditinjau dari unsur materi bahan ajar $(4,32)$ atau dengan kategori sangat layak, unsur penyajian $(4,07)$ atau dengan kategori layak, unsur kegrafikan $(4,33)$ atau dengan kategori sangat layak, unsur kebahasaan $(4,19)$ atau dengan kategori layak, dan terakhir unsur media atau teknologi $(4,19)$ dengan kategori layak. Rerata penilaian subjek uji coba satu-satu yang berjumlah enam mahasiswa adalah $(3,75)$ atau dengan kategori layak, rerata penilaian kelayakan subjek uji coba lapangan utama yaitu $(4,38)$ dengan kategori sangat layak, dan rerata penilaian kelayakan subjek uji coba lapangan operasional yaitu 4,38 dengan kategori sangat layak. Bahan ajar memiliki tingkat keterbacaan yang baik dengan rerata persentase sebesar $(81,45 \%)$ lebih besar dari standar independensi kebebasan $(60 \%)$. Hasil penilaian keterlaksanaan bahan ajar membuktikan bahwa rerata evaluasi program pembelajaran kelas implementasi 1 sebesar $(4,25)$ atau dengan kategori sangat layak, kelas implementasi 2 sebesar $(4,40)$ atau dengan kategori sangat layak, dan kelas implementasi 3 sebesar $(4,60)$ atau dengan kategori sangat layak. Selanjutnya, pengelolaan pemakaian bahan ajar di dalam pembelajaran menunjukkan hasil yang sangat baik. Bahan ajar diimplementasikan secara maksimal di mana rerata kelas implementasi 1 sebesar $(4,20)$ atau dengan kategori sangat praktis, kelas implementasi 2 sebesar $(4,60)$ atau dengan kategori sangat praktis, dan kelas implementasi 3 sebesar $(4,50)$ atau dengan kategori sangat praktis. Bahan ajar layak digunakan karena efektif terhadap peningkatan hasil belajar mahasiswa. Hasil tes membuktikan bahwa terjadi peningkatan ketuntasan belajar mahasiswa. Hasil tes kemampuan awal hanya (22\% ) mahasiswa yang dinyatakan tuntas sedangkan hasil tes kemampuan akhir sebanyak $(76 \%)$.
\end{abstract}

Kata kunci: Bahan Ajar, Kajian Apresiasi Prosa Fiksi, Mobile Learning

\begin{abstract}
The purpose of this research is to create study materials of fictional prose based on local wisdom of Makassar integrated mobile learning that is feasible or valid, readability, practical and effective for the students of Indonesian Language and Literature Education Study Program at Muhammadiyah University of Makassar.This research type is research and development or Research and Development $(R \& D)$ by using model of ADDIE (Analyze, Design, Develop, Implement, Evaluation). Data collection techniques include test techniques, questionnaires, observation, interviews, and documentation. Data analysis techniques used descriptive qualitative analysis techniques and descriptive statistics. In this research, it is found that the appropriate or valid teaching material is evaluated from the teaching material element (4.32) or with the category very feasible, the presentation element (4.07) or with the decent category, the element of kegrafikan $(4,33)$ or with the category very feasible, linguistic element $(4.19)$ or by a viable category, and the last element of media or technology (4.19) with a decent category. The average of oneto-one subject assessment subjects totaling six students is (3.75) or with the appropriate category, the average of the feasibility of the main field trial subjects (4.38) with very feasible category, and the average assessment of the feasibility of the field trial operational is 4.38 with very decent category.
\end{abstract}


Teaching materials have a good level of legibility with a mean percentage of $(81.45 \%)$ greater than the independence independence standard (60\%). The result of the assessment of teaching materials implementation proves that the average of evaluation of 1st class implementation learning program is (4.25) or with very decent category, implementation class 2 is (4.40) or with very decent category, and implementation class 3 is 4.60 ) or in a very decent category. Furthermore, the use of teaching materials in learning shows excellent results. The teaching materials are implemented maximally where the average implementation class 1 is (4.20) or in very practical category, the implementation class 2 is (4.60) or in the very practical category, and the implementation class 3 is (4.50) or with category very practical.Teaching materials are worth using because they are effective towards improving student learning outcomes. The test results prove that there is an increase in students' learning mastery. The result of the initial skill test is only (22\%) of the students who is declared thoroughly while the final skill test result is $(76 \%)$.

\section{Keywords: Teaching Materials, Appraisal Appraisal Prose Fiction, Mobile Learning}

\section{PENDAHULUAN}

Rasionalisasi perkembangan teknologi dan komunikasi sekarang ini seharusnya direpresentasikan dalam dunia pendidikan sebagai wadah peletakan dasar penciptaannya. Hal tersebut mengacu pada peran strategis teknologi dalam dunia pendidikan yang semakin tidak terelakkan untuk dijalankan secara sinergis. Di perguruan tinggi, teknologi dan kinerja profesionalitas seorang dosen adalah dua hal yang tidak dapat terpisahkan. Esensi kredibiltas seorang dosen saat ini tidak hanya diukur dari tinggi atau rendahnya jenjang pendidikan, tetapi juga kemampuannya dalam berkreasi dan berinovasi untuk melahirkan ide atau gagasan-gagasan baru yang tepat guna dengan bersikap adaftif dan reflektif terhadap lingkungannya.

Salah satu bentuk kompetensi profesionalitas seorang dosen adalah mengajar. Mengajar melibatkan berbagai aspek yang saling terkait satu sama lain seperti pemilihan metode yang tepat, pemilihan media pembelajaran, pengelolaan kelas, penggunaan bahan ajar yang tepat, serta berbagai aspek lainnya. Terkait dengan bahan ajar, produk ini memiliki peran yang sangat strategis dalam menyukseskan proses dan pencapaian tujuan pembelajaran. Pada hakikatnya, bahan ajar tidak hanya dijadikan sebagai sumber materi yang akan dipelajari oleh mahasiswa. Tetapi, bahan ajar dapat pula dijadikan sebagai sarana pendidikan karakter dan kebudayaan seperti pada penelitian berikut.

Bahan ajar terkait sebagai sarana pendidikan karakter serupa dengan penelitian disertasi yang dilakukan oleh Batari (2014) yang berjudul "Pengembangan Bahan Ajar Bahasa Indonesia Berbasis Cerita Rakyat Siswa Kelas III Sekolah Dasar di Kabupaten Gowa". Hasil dari penelitian ini meningkatkan keterampilan berbahasa serta menanamkan dan mengaplikasikan nilai-nilai karakter pada peserta didik sehingga terbentuk budi pekerti yang diharapkan. Selanjutnya, bahan ajar terkait sebagai sarana pendidikan budaya lokal serupa dengan penelitian yang dilakukan oleh Akib (2007) yang berjudul "Model Pembelajaran Matematika Berbasis Budaya Bugis Makassar". ". Tujuan penelitian ini adalah untuk memperoleh suatu model pembelajaran matematika yang berkualitas, yaitu model pembelajaran matematika berbasis budaya Bugis-Makassar (Model BBM). Adapun manfaat dari penelitian pengembangan ini adalah menghasilkan suatu model pembelajaran matematika yang berbasis budaya Bugis-Makassar, hasil penelitian ini diharapkan dapat memperkaya pengetahuan guru matematika sebagi dasar untuk meningkatkan kualitas pembelajarannya. Guru dapat merencanakan berbagai aktivitas pembelajaran matematika 
dengan mempertimbangkan budaya BugisMakassar. Mengacu pada peran penting teknologi dalam dunia pendidikan dan hasil penelitian-penelitian tersebut, pengembangan bahan ajar semakin tidak terbantahkan kepentingannya.

Namun, menjadi keprihatinan tersendiri bahwa pembelajaran di Universitas Muhammadiyah Makassar khususnya dalam pembelajaran kajian prosa fiksi belum sepenuhnya mengacu pada paradigma pembelajaran yang basisnya kearifan lokal terintegrasi teknologi yang mampu mengefektifkan dan mengefisienkan proses dan pencapaian tujuan pembelajaran. Hal ini dapat dilihat dari sumber dan bahan ajar yang biasa digunakan. Dosen maupun mahasiswa sebagian besar mengandalkan sumber dan bahan ajar cetak seperti makalah, literatur, handout, dan jenis bahan ajar cetak lainnya yang masih berlaku umum. Belum ada bahan ajar kajian apresiasi prosa fiksi yang secara sfesifik memasukkan kearifan budaya lokal di dalam bahan ajar.

Pengembangan bahan ajar kajian prosa fiksi sebelumnya pernah dilakukan oleh peneliti. Namun, masih dalam bentuk bahan ajar cetak untuk kepentingan pembelajaran pada mahasiswa FKIP di Universitas Muhammadiyah Makassar. Bahan ajar tersebut juga masih berlaku umum. Belum ada kearifan budaya lokal di dalamnya. Setelah dilakukan evaluasi terhadap bahan ajar cetak tersebut, peneliti menemukan berbagai kelemahan seperti; materi bahan ajar yang kurang memadai; media yang digunakan belum diintegrasikan dengan teknologi; bahan ajar masih dikemas dalam bentuk produk cetak (buku), serta berbagai kelemahan dalam hal penulisan dan tatabahasa.

Berdasarkan fakta tersebut, peneliti berinisiatif untuk mengembangkan bahan ajar kajian prosa fiksi berbasis kearifan budaya lokal Makassar yang memanfaatkan teknologi telepon genggam yang terintegrasi dengan sistem android sebagai medianya.
Kearifan budaya lokal Makassar yang dimaksud dalam penelitian ini adalah kebudayaan tak benda (immaterial) berupa nilai-nilai luhur masyarakat Makassar yang menjadi identitas manusia Makassar seperti siri' atau malu, kejujuran, kecendekiaan, keteguhan, kepatutan, serta usaha atau kerja keras yang diambil atau dikutip dalam karya prosa fiksi seperti novel atau cerpen. Spesifikasi bahan ajar yang akan dikembangkan berupa aplikasi pembelajaran yang berisi materi pelajaran kajian prosa fiksi. Bahan ajar tersebut nantinya dapat diakses kapan pun dan di mana pun tanpa harus terkoneksi dengan jaringan internet. Hal ini tentunya dinilai lebih efektif dan efisien untuk diterapkan dalam pembelajaran daripada kondisi pembelajaran sebelumnya.

Harapan efektifnya pembelajaran dengan menerapkan teknologi di dalamnya sejalan dengan pandangan Vavoula dan Sharples (2009) bahwa di era perkembangan teknologi canggih sekarang ini, mobile learning (M-Learning) adalah salah satu peluang yang potensial untuk mengembangkan mutu dan kualitas pembelajaran. Kehadiran mobile learning dalam dunia pendidikan adalah salah satu inovasi teknologi pendidikan yang memberikan kemudahan bagi setiap dosen dan mahasiswa untuk mengajar dan belajar secara dinamis.

Hasil pengembangan bahan ajar ini nantinya sebagai pelopor model pembelajaran yang terintegrasi mobile learning (M-Learning) berbasis kearifan lokal Makassar pada mahasiswa FKIP di Universitas Muhammadiyah Makassar. Karena, sampai saat ini, model pembelajaran tersebut (M-Learning) belum diterapkan secara konsisten. Selain itu, belum ada bahan ajar yang biasa digunakan di Universitas Muhammadiyah Makassar serupa dengan bahan ajar yang akan dikembangkan.

Berdasarkan latar belakang yang telah dikemukakan di atas, rumusan masalah dalam penelitian ini ada empat yaitu yang 
pertama bagaimanakah kelayakan bahan ajar kajian prosa fiksi berbasis kearifan lokal Makassar terintegrasi mobile learning untuk mahasiswa FKIP di Universitas Muhammadiyah Makassar, selanjutnya yang kedua bagaimanakah keterbacaan bahan ajar kajian prosa fiksi berbasis kearifan lokal Makassar terintegrasi mobile learning untuk mahasiswa FKIP di Universitas Muhammadiyah Makassar, selanjutnya yang ketiga bagaimanakah kepraktisan bahan ajar kajian prosa fiksi berbasis kearifan lokal Makassar terintegrasi mobile learning untuk mahasiswa FKIP di Universitas Muhammadiyah Makassar dan yang keempat yaitu Bagaimanakah keefektifan bahan ajar bahan ajar kajian prosa fiksi berbasis kearifan lokal Makassar terintegrasi mobile learning untuk mahasiswa FKIP di Universitas Muhammadiyah Makassar?

\section{TINJAUAN PUSTAKA}

\section{a. Teori Sastra}

Sastra adalah suatu kegiatan kreatif, sebuah karya seni (Wellek \& Warren, 2014: 3). Dalam bidang sastra, sering disebutkan istilah seperti prosa dan fiksi. Istilah prosa sendiri diidentikkan dengan kata fiksi yang berarti khayalan atau tidak berdasarkan kenyataan. Hakikat sastra adalah karya yang indah yang merupakan kreativitas pengarang yang melibatkan imajinasi dan kemampuan membahasakan realita. Selain bercirikan keindahan, sebuah karya sastra haruslah memiliki kegunaan.

Ciri-ciri sastra khusus kekhasannya pada masa Romantik. Luxemburg (Sumardjo \& Saini, 1994 : 5) menyebut ciri sastra yaitu Sastra adalah sebuah ciptaan atau kreasi, Sastra bersifat otonom, Sastra memiliki unsur koherensi, Sastra berisi tentang sintesis atau unsur-unsur yang selama ini dianggap bertentangan, dan Sastra berisi ungkapan-ungkapan yang tidak bias terungkapkan.Sastra dapat digolongkan menjadi dua kelompok jenisnya yakni sastra imajinatif dan sastra non imajinatif. Dalam penggolongan sastra yang pertama, ciri khayali sastra agak kuat dibanding dengan sastra non imajinatif. Begitu pula dalam penggunaan bahasanya, sastra imajinatif lebih menekankan penggunaan bahasa konotatif (banyak arti) dibandingkan dengan sastra non imajinatif yang lebih menekankan pada penggunaan bahasa denotatif (tunggal arti). Dan karya sastra sebagai karya kreatif terbagi dalam tiga jenis yaitu puisi, fiksi, dan drama. Masing-masing jenis karya sastra memiliki ciri-ciri yang khas.

\section{b. Teori Prosa Fiksi}

Pengertian prosa fiksi tersebut adalah kisahan atau cerita yang diemban oleh pelaku-pelaku tertentu dengan pemeranan, latar serta tahapan serta rangkaian cerita tertentu yang bertolak dari hasil imajinasi pengarangnya sehingga menjalin suatu cerita (Aminuddin, 2011: 66). Prosa dalam pengertian kesastraan juga disebut fiksi, teks naratif atau wacana naratif. Istilah fiksi adalah cerita rekaan atau cerita khayalan yang berbentuk prosa, prosa naratif atau teks naratif.

Kata novel berasal dari bahasa Latin novellas, yang terbentuk dari kata novus yang berarti baru atau new dalam bahasa Inggris. Mengapa dikatakan baru? Karena novel adalah bentuk karya sastra yang datang dari karya sastra lainnya seperti puisi dan drama. Istilah novel tidak hanya diterapkan untuk berbagai tulisan yang indah yang hanya dikembangkan dalam karya fiksi prosa. Sebagai cerita naratif yang berkembang, novel dibedakan dari cerita pendek dan dari hasil karya yang agak panjang yang dinamakan novelet (Abrams, 1981: 110). Cerpen adalah salah satu jenis prosa fiksi yang memiliki ciri dasar seperti novel. Ciri dasar menurut bentuk fisiknya, cerita pendek (atau disingkat menjadi cerpen) adalah cerita yang pendek.

\section{c. Teori Pembelajaran Sastra}

Pembelajaran menurut Joyoatmojo (2003: 29) dapat dipahami sebagai suatu proses mengajak peserta didik bekerjasama 
dalam rangka membantu mereka mengubah pemahaman tentang sesuatu. Aspek-aspek dalam pembelajaran meliputi: manusia, material, fasilitas, perlengkapan, dan prosedur yang saling memengaruhi dan berkonstribusi untuk mencapai tujuan pembelajaran (Gagne, 1984). Pembelajaran sastra melalui perspektif pendidikan sastra yang mencoba untuk mengembangkan kompetensi apresiasi sastra, kritik sastra dan proses kreatif sastra (Siswanto , 2008: 168169).

\section{d. Teori Pembelajaran Prosa Fiksi}

Karya sastra prosa biasa juga disebut sebagai fiksi atau cerita rekaan. Jenis karya sastra ini berupa kisah atau cerita yang dikembangkan oleh pelaku-pelaku tertentu dengan pemeran, tahap, dan rangkaian cerita tertentu yang bertolak dari hasil imajinasi pengarangnya sehingga terjalin suatu cerita. Beberapa jenis prosa fiksi seperti; cerpen, novel, dan roman. Di dalam pembelajaran prosa fiksi, peserta didik tidak hanya diarahkan untuk mengenal dan membaca karya-karya tersebut, melainkan ada tujuan hakiki yang hendak dicapai dalam dunia pendidikan sastra.

\section{e. Kurikulum Pengajaran Sastra di Perguruan Tinggi}

Berbeda dengan jenjang pendidikan lainnya. Di perguruan tinggi, mata kuliah sastra dibelajarkan secara terpisah dengan bahasa Indonesia. Dengan demikian, mahasiswa benar-benar belajar secara terkonsentrasi pada sastra. Namun, tidak dapat dipungkiri bahwa belajar mata kuliah apa pun tentunya akan mengarah pada peningkatan keterampilan berbahasa mahasiswa yaitu keterampilan menyimak, berbicara, menulis, dan membaca (Emzir \& Rahman, 2015:255). Secara umum, kurikulum sastra dikembangkan dengan mengacu pada tujuan yang akan dicapai yaitu untuk mengembangkan kompetensi apresiasi sastra, kritik sastra dan proses kreatif sastra. Kompetensi apresiasi sastra yang diasah dalam pendidikan ini adalah kemampuan menikmati dan menghargai karya sastra. Pendidikan semacam ini mengajak peserta didik untuk langsung membaca, memahami, menganalisis, dan menikmati karya sastra secara langsung (Siswanto, 2008: 168-169).

\section{f. Teori Pengembangan}

Pada hakikatnya pengembangan adalah upaya pendidikan baik formal maupun non formal yang dilaksanakan secara sadar, berencana, terarah, teratur dan bertanggung jawab dalam rangka memperkenalkan, menumbuhkan, membimbing, mengembangkan suatu dasar kepribadian yang seimbang, utuh, selaras, pengetahuan, keterampilan sesuai dengan bakat, keinginan serta kemampuan-kemampuan, sebagai bekal atas prakarsa sendiri untuk menambah, meningkatkan, mengembangkan diri ke arah tercapainya martabat, mutu dan kemampuan manusiawi yang optimal serta pribadi mandiri (Wiryokusumo, 2007:42).

\section{g. Teori Pengembangan Bahan Ajar}

Bahan ajar itu adalah segala bentuk bahan/seperangkat materi/substansi pelajaran (teaching material)yang disusun secara sistematis, dapat dicetak atau noncetak, digunakan sebagai sumber belajar berupa materi audio visual (software/hardware)yang dapat digunakan sebagai alternatif dalam berkomunikasi pada proses belajar mengajar, yang secara garis besar terdiri dari pengetahuan,keterampilan, sikap yang harus dipelajari peserta didik dalam rangka mencapai standar kompetensi yang telah ditentukan.

Di samping itu, (Prastowo, 2013:43) juga menambahkan beberapa tujuan pembuatan bahan ajar yang setidaknya ada empat hal pokok yang melingkupinya, yaitu: (1) membantu peserta didik dalam mempelajari sesuatu, (2) menyediakan berbagai jenis pilihan bahan ajar, (3) memudahkan dosen dalam melaksanakan pembelajaran, (4) agar kegiatan pembelajaran menjadi menarik.Dan 
manfaat dari bahan ajar yang dikembangkan oleh pendidik itu sendiri secara garis besar dapat didesain sesuai dengan kurikulum yang relevan, sesuai kebutuhan dan karakeristik peserta didik itu sendiri, sehingga tujuan yang diharapkan akan tercapai. jenis-jenis bahan ajar digolongkan menjadi dua, yaitu bahan ajar yang besifat cetak dan non cetak.

Bahan ajar cetak dapat digunakan dalam pembelajaran tanpa bantuan teknologi seperti komputer, LCD proyektor, dan lainya, sedangkan bahan ajar non cetak lebih banyak digunakan dengan memanfaatkan teknologi tersebut.

\section{h. Pengembangan Bahan Ajar Digital.}

Pada dasarnya dalam pengembangan bahan ajar digital memerlukan pengetahuan dan keterampilan pendukung yang memadai, terutama di dalam mengoperasikan peralatan seperti komputer, kamera video, dan kamera foto serta dalam persiapan dan pembuatannya. Menurut pedoman pengembangan bahan ajar Departemen Pendidikan Nasional (2006) evaluasi ini dimaksudkan untuk mengetahui apakah bahan ajar telah baik ataukah masih ada hal yang perlu diperbaiki. Komponen evaluasi bahan ajar mencakup: (1) kelayakan isi (materi pelajaran), (2) kebahasaan, (3) penyajian,dan (4) grafika.

\section{i. Kualitas Bahan Ajar Yang Baik}

Kualitas bahan ajar dapat mengacu pada kualitas menurut Nieveen (1999:27) menyatakan "kita telah menunjukkan mutu produk pendidikan dari sudut pandang pengembangan materi pembelajaran. Tetapi kita juga mempertimbangkan tiga aspek mutu (validitas, kepraktisan, dan keefektifan) dapat digunakan pada rangkaian produk yang lebih luas". Pada penelitian pengembangan ini, peneliti mengukur tingkat kepraktisan bahan ajar dengan melihat dari apakah pendidik menyatakan bahwa bahan ajar dapat digunakan oleh pendidik dan peserta didik dan tingkat keterlaksaannya, pembelajaran menggunakan bahan ajar termasuk kategori baik dengan melihat apakah komponenkomponen bahan ajar untuk pembelajaran dapat dilaksanakan oleh pendidik di kelas.

\section{j. Mobile Learning}

Istilah mobile learning (m-learning) mengacu kepada penggunaan perangkat/divais teknologi informasi (TI) genggam dan bergerak, seperti PDA, telepon genggam, Laptop dan tablet PC, dalam pengajaran dan pembelajaran. Beberapa kemampuan penting yang harus disediakan oleh perangkat pembelajaran M-Learning adalah adanya kemampuan untuk terkoneksi ke peralatan lain (terutama komputer), kemampuan menyajikan informasi pembelajaran dan kemampuan untuk merealisasikan komunikasi bilateral antara dosen dan mahasiswa. Terdapat tiga fungsi M-Learning dalam kegiatan pembelajaran di dalam kelas (classroom instruction), yaitu sebagai suplemen (tambahan) yang sifatnya pilihan (opsional), pelengkap (komplemen), atau pengganti (subtitusi).

\section{k. Kearifan Lokal}

Kearifan lokal dapat pula didefinisikan sebagai nilai-nilai luhur yang terkandung dalam kekayaan-kekayaan budaya berupa tradisi, pepatah-petitih, dan semboyan hidup. Di samping itu, konsep kearifan lokal atau kearifan tradisional atau sistem pengetahuan lokal adalah pengetahuan khas milik suatu masyarakat atau budaya tertentu yang telah berkembang lama sebagai hasil dari proses hubungan timbal-balik antara masyarakat dan lingkungannya. Dalam penelitian dan pengembangan ini, berbasis kearifan lokal Makassar, bahan ajar yang dikembangkan bukanlah kearifan lokal Makassar dalam bentuk sastra melainkan nilai-nilai luhur yang mencerminkan kepribadian atau identitas manusia Makassar yang tertuang di dalam karya sastra bergenre prosa berupa novel atau cerpen yang ditulis oleh sastrawan Makassar atau sastrawan yang 
berasal dari daerah lain yang isinya menceritakan kebudayaan Makassar.

\section{METODE PENELITIAN}

Penelitian ini adalah penelitian dan pengembangan (Research and Development). Penelitian dan pengembangan digunakan untuk menghasilkan produk tertentu, dan menguji keefektifan produk tersebut Sugiyono ( 2013:94). R\&D adalah penelitian yang bertujuan menghasilkan produk berdasarkan temuan-temuan dari serangkaian uji coba, misalnya melalui perorangan, kelompok kecil, kelompok sedang, dan uji lapangan kemudian dilakukan revisi dan seterusnya untuk mendapatkan hasil atau produk yang memadai atau layak pakai, Setyosari (2013).

Fokus dalam penelitian dan pengembangan ini adalah mengembangkan dan menghasilkan bahan ajar kajian apersiasi prosa fiksi berbasis kearifan lokal Makassar terintegrasi mobile learning yang telah memenuhi syarat kelayakan, keterbacaan, keefektifan, dan kepraktisan.

1) Menghitung rerata semua observer untuk semua kriteria dengan rumus:

$$
\overline{\boldsymbol{K} i}=\frac{\sum_{j=1}^{n} V_{i j}}{n}, \text { dengan }
$$

$\overline{K i}=$ rerata kriteria ke $\mathrm{i}$

$V_{i j}=$ skor hasil penilaian terhadap kriteria

ke $i$ oleh penilai ke $j$

$n=$ banyaknya validator

2) Menghitung rerata tiap aspek dengan rumus

$$
\overline{A \boldsymbol{i}}=\frac{\sum_{j=1}^{n} \bar{K}_{i j}}{n}
$$

$\overline{A \boldsymbol{i}}=$ rerata aspek ke $i$

$\bar{K}_{i j}=$ rerata untuk aspek ke $i$ kriteria ke $j$, dan
Subjek uji coba dalam penelitian ini adalah mahasiswa semester genap (IV) Program Studi Pendidikan Bahasa dan Sastra Indonesia tahun ajaran 2016/2017 sebanyak 238 orang yang terbagi menjadi enam kelas. Selanjutnya, sampel penelitian dipilih dengan teknik acak (random sampling). Teknik pengumpulan data dalam penelitian dan pengembangan ini mengacu pada jenis instrumen yang digunakan. Ada dua teknik yang digunakan untuk mengumpulkan data yaitu teknik tes dan teknik nontes. Data kelayakan bahan ajar yang dikembangkan berupa pendapat ahli materi dan ahli media, serta mahasiswa. Hasil tersebut dianalisis dan dijabarkan secara kualitatif dan kuantitatif.

Data keterlaksanaan dan pengelolaan bahan ajar dalam pembelajaran diperoleh melalui angket yang diisi oleh observer pembelajaran (peneliti sendiri). Mula-mula, observer mengamati pembelajaran untuk memahami keterlaksanaan dan pengelolaan bahan ajar dalam pembelajaran. Setelah itu, observer mengisi angket berdasarkan hasil pengamatannya. Data ini di analisis dengan langkah sebagai berikut:

$n=$ banyaknya kriteria dalam aspek ke $i$

3) Menghitung rerata total ( $\bar{X})$ dengan rumus :

$\bar{X}=$ Rerata total

$$
\overline{\boldsymbol{X}}=\frac{\sum_{i=1}^{n} \bar{A}_{i}}{n}
$$

$\bar{A}_{i}=$ rerata aspek ke $i$

$n=$ banyaknya aspek

(Nurdin dalam Anshari dan Muhammad Saleh, 2013:34)

4) Menentukan kategori untuk pengelolaan dan keterlaksanaan bahan ajar dalam pembelajaran berdasarkan kategori berikut. 
Tabel 1. Konversi Kepraktisan Klasikal ke Data Kualitatif dengan Skala 5

\begin{tabular}{|c|c|c|}
\hline Interval Skor & Nilai & Kategori \\
\hline $\mathrm{X} \geq 4,2$ & 5 & Sangat Baik \\
\hline $3,4<\mathrm{X} \leq 4,2$ & 4 & Baik \\
\hline $2,6<\mathrm{X} \leq 3,40$ & 3 & Cukup Baik \\
\hline $1,8<\mathrm{X} \leq 2,6$ & 2 & Kurang Baik \\
\hline $\mathrm{X} \leq 1,8$ & 1 & Sangat Kurang Baik \\
\hline
\end{tabular}

\section{HASIL PENELITIAN DAN PEMBAHASAN}

a. Deskripsi Kelayakan Bahan Ajar Kajian Apresiasi Prosa Fiksi Berbasis Kearifan Lokal Terintegrasi Mobile Learning Mahasiswa FKIP Universitas Muhammadiyah Makassar
Kelayakan bahan ajar ini ditunjukkan oleh hasil validasi dari dua orang ahli (expert) yang menilai materi bahan ajar, sistematika penyajian bahan ajar, tata kegrafikan bahan ajar, bahasa, dan media atau teknologi yang digunakan. Adapun hasil validasi pakar sebagai berikut:

Tabel 2.Hasil Validasi Materi Bahan Ajar (Tahap 1)

\begin{tabular}{|l|c|c|c|c|}
\hline \multirow{2}{*}{ Aspek } & \multicolumn{2}{|c|}{ Rerata Validator } & \multirow{2}{*}{$\begin{array}{c}\text { Rerata } \\
\text { Aspek }\end{array}$} & Keterangan \\
\cline { 2 - 3 } & I & II & 3.00 & Cukup \\
\hline $\begin{array}{l}\text { Kesesuaian Materi dengan } \\
\text { SK dan KD }\end{array}$ & 3.00 & 3.00 & 3.25 & Cukup \\
\hline Keakuratan Materi & 3,50 & 3.00 & 3.00 & Cukup \\
\hline Kemutakhiran Materi & 3.00 & 3.00 & 2.50 & Kurang \\
\hline $\begin{array}{l}\text { Mendorong } \\
\text { Keingintahuan }\end{array}$ & 2.50 & 2.00 & 2,85 & Cukup \\
\hline Rerata Total & 2,94 & 2.75 & & \\
\hline
\end{tabular}

Tabel di atas menunjukkan bahwa rerata aspek kesesuaian materi dengan Standar Kompetensi (SK) dan Kompetensi Dasar (KD) hanya sebesar 3.00 dengan kategori cukup. Artinya bahan ajar belum layak digunakan. Rerata aspek keakuratan materi sebesar 3,25 dengan kategori cukup sehingga aspek ini juga dinilai belum layak pada bahan ajar dan membutuhkan perbaikan. Aspek selanjutnya yang dinilai belum layak adalah kemutakhiran materi. Rerata aspek ini hanya sebesar 3.00 dengan kategori cukup. Menurut kedua ahli, ketidakmutakhiran materi disebabkan oleh pemakaian materi-materi yang bukan berasal dari referensi terbaru. Rerata total aspek materi bahan ajar sebesar 2,85 dengan kategori cukup layak tetapi belum memenuhi syarat yang ditentukan sehingga membutuhkan perbaikan secara serius.

Tabel 3. Hasil Validasi Materi Bahan Ajar (Tahap 2)

\begin{tabular}{|l|c|c|c|c|}
\hline \multirow{2}{*}{ Aspek } & \multicolumn{2}{|c|}{ Rerata Validator } & \multirow{2}{*}{$\begin{array}{c}\text { Rerata } \\
\text { Aspek }\end{array}$} & Keterangan \\
\cline { 2 - 3 } & I & II & 4.00 & Layak \\
\hline $\begin{array}{l}\text { Kesesuaian Materi dengan } \\
\text { SK dan KD }\end{array}$ & 4,00 & 4,00 & 4,25 & Sangat Layak \\
\hline Keakuratan Materi & 4,00 & 4,00 & 4,25 \\
\hline
\end{tabular}




\begin{tabular}{|l|c|c|c|c|}
\hline Kemutakhiran Materi & 4,60 & 4,50 & 4.50 & Sangat Layak \\
\hline $\begin{array}{l}\text { Mendorong } \\
\text { Keingintahuan }\end{array}$ & 4,50 & 4,50 & 4.50 & Sangat Layak \\
\hline Rerata Total & 4,28 & 4,25 & 4,32 & Sangat Layak \\
\hline
\end{tabular}

Tabel di atas menunjukkan bahwa hasil perbaikan atau revisi bahan ajar tahap 2 telah dinyatakan layak. Para ahli menilai materi bahan ajar hasil revisi dikembangkan sesuai dengan SK dan KD sehingga rerata aspek ini sebesar 4.00 dengan kategori layak. Setingkat lebih baik dari kedua aspek di atas, aspek kemutakhiran materi dan mendorong keingintahuan dinilai sangat layak oleh kedua ahli. Rerata aspek kemutakhiran materi sebesar 4.50 dengan kategori sangat layak. sedangkan aspek mendorong keingintahuan sebesar 4.50 dengan kategori sangat layak. rerata total aspek materi sebesar 4,32 dengan kategori sangat layak.

Tabel 4. Hasil Validasi Sistematika Penyajian Bahan Ajar (Tahap 1)

\begin{tabular}{|l|c|c|c|c|}
\hline \multirow{2}{*}{\multicolumn{1}{|c|}{ Aspek }} & \multicolumn{2}{|c|}{ Rerata Validator } & \multirow{2}{*}{ Rerata Aspek } & \multirow{2}{*}{ Keterangan } \\
\cline { 2 - 3 } & I & II & & Kurang \\
\hline Teknik Penyajian & 2,00 & 2,00 & 2,00 & Kurang \\
\hline Pendukung Penyajian & 2,50 & 2,00 & 2,25 & Cukup \\
\hline Penyajian Pembelajaran & 3,00 & 3,00 & 3,00 & Kurang \\
\hline $\begin{array}{l}\text { Koherensi dan keruntutan } \\
\text { alur piker }\end{array}$ & 2,50 & 2,00 & 2,25 & Kurang \\
\hline Rerata Total & 2,50 & 2,25 & 2,37 & \\
\hline
\end{tabular}

Serupa dengan aspek materi bahan ajar, setelah dilakukan pemeriksaan kevalidan, peneliti kembali membaca dan menganalisis keinginan para ahli terkait bagian-bagian bahan ajar yang harus direvisi guna mendapatkan hasil yang lebih baik. Setelah dilakukan revisi, bahan ajar kembali divalidasi oleh kedua ahli dengan hasil seperti pada tabel berikut:

Tabel 5. Hasil Validasi Sistematika Penyajian Bahan Ajar (Tahap 2)

\begin{tabular}{|l|c|c|c|c|}
\hline \multirow{2}{*}{ Aspek } & \multicolumn{2}{|c|}{ Rerata Validator } & \multirow{2}{*}{$\begin{array}{c}\text { Rerata } \\
\text { Aspek }\end{array}$} & Keterangan \\
\cline { 2 - 3 } & I & II & 4,25 & Sangat Layak \\
\hline Teknik Penyajian & 4,00 & 4,50 & 4,00 & Layak \\
\hline Pendukung Penyajian & 4,00 & 4,00 & 4,00 & Layak \\
\hline Penyajian Pembelajaran & 4,00 & 4,00 & 4,00 & Layak \\
\hline $\begin{array}{l}\text { Koherensi dan keruntutan } \\
\text { alur piker }\end{array}$ & 4,00 & 4,00 & 4,07 & Layak \\
\hline Rerata Total & 4,00 & 4,13 & &
\end{tabular}

Tabel menunjukkan hasil validasi bahan ajar tahap 2 setelah dilakukan revisi tahap 1 . Tabel tersebut membuktikan bahwa bahan ajar telah dinyatakan layak. Rerata total aspek teknik penyajian bahan ajar adalah 4,25 dengan kategori sangat. Rerata aspek pendukung penyajian sebesar 4,00 dengan kategori layak. aspek ini sama dengan penilaian aspek teknik penyajian. Untuk aspek penyajian pembelajaran dan aspek koherensi dan keruntutan alur pikir, juga 
dinyatakan layak berdasarkan hasil validasi dengan rerata aspek masing-masing 4,00.
Hasil penilaian kevalidan bahan ajar unsur tata kegrafikan bahan ajar disajikan dalam tabel berikut:

Tabel 6. Hasil Validasi Kegrafikan Bahan Ajar Bahan Ajar (Tahap 1)

\begin{tabular}{|l|c|c|c|c|}
\hline \multirow{2}{*}{ Aspek } & \multicolumn{2}{|c|}{ Rerata Validator } & \multirow{2}{*}{$\begin{array}{c}\text { Rerata } \\
\text { Aspek }\end{array}$} & Keterangan \\
\cline { 2 - 3 } & I & II & 4,00 & Layak \\
\hline $\begin{array}{l}\text { Ukuran Bahan Ajar Cetak } \\
\text { (opsional) }\end{array}$ & 4,00 & 4,00 & 2,50 & Kurang \\
\hline Desain Sampul & 2,00 & 3,00 & 2,50 & Kurang \\
\hline Desain isi bahan ajar & 3,00 & 2,00 & 3,00 & Cukup \\
\hline Rerata Total & 3,00 & 3,00 & & \\
\hline
\end{tabular}

Hasil validasi tersebut kembali dibaca dan dianalisis oleh peneliti sebelum melakukan revisi atau perbaikan sesuai dengan keinginan validator. Namun, khusus pada aspek ukuran bahan ajar, peneliti tidak lagi melakukan revisi karena telah dinyatakan layak. kemudian, menurut komentar kedua ahli bahwa pada aspek ini sesuai dengan keinginan pengguna bahan ajar yang hakikatnya sesuai dengan perkembangan ilmu pengetahuan dan teknologi. Adapun hasil validasi tahap kedua seperti pada tabel berikut:

Tabel 7. Hasil Validasi Tata Kegrafikan Bahan Ajar (Tahap 2)

\begin{tabular}{|l|c|c|c|c|}
\hline \multirow{2}{*}{\multicolumn{1}{|c|}{ Aspek }} & \multicolumn{2}{|c|}{ Rerata Validator } & \multirow{2}{*}{$\begin{array}{c}\text { Rerata } \\
\text { Aspek }\end{array}$} & \multirow{2}{*}{ Keterangan } \\
\cline { 2 - 3 } & I & II & Layak \\
\hline $\begin{array}{l}\text { Ukuran Bahan Ajar } \\
\text { Cetak (opsional) }\end{array}$ & 4,00 & 4,00 & 4,00 & Sangat Layak \\
\hline Desain Sampul & 5,00 & 4,50 & 4,75 & Sangat Layak \\
\hline Desain isi bahan ajar & 4,00 & 4,50 & 4,25 & Sangat Layak \\
\hline Rerata Total & 4,33 & 4,33 & 4,33 & \\
\hline
\end{tabular}

Tabel 4.7 di atas menunjukkan hasil validasi unsur tata kegrafikan bahan ajar yang semua aspeknya telah dinyatakan memenuhi syarat kelayakan.Rerata aspek desain sampul sebesar 4,75 atau dengan kategori sangat layak.Rerata desain isi bahan ajar sebesar 4,25 atau dengan kategori sangat layak. Namun, menurut kedua ahli kriteria yang harus diperhatikan adalah penggunaan spasi dan sistem penomoran.

Tabel 8. Hasil Validasi Kebahasaan Bahan Ajar (Tahap 1)

\begin{tabular}{|c|c|c|c|c|}
\hline \multirow{2}{*}{ Aspek } & \multicolumn{2}{|c|}{ Rerata Validator } & \multirow{2}{*}{$\begin{array}{c}\text { Rerata } \\
\text { Aspek }\end{array}$} & \multirow{2}{*}{ Keterangan } \\
\hline & I & II & & \\
\hline Lugas & 3,00 & 3,25 & 3,13 & Cukup \\
\hline Komunikatif & 3,50 & 3,00 & 3,25 & Cukup \\
\hline Dialogis dan interaktif & 2,75 & 3,00 & 2,88 & Cukup \\
\hline $\begin{array}{l}\text { Kesesuaian dengan } \\
\text { perkembangan peserta } \\
\text { didik }\end{array}$ & 3,50 & 3,00 & 3,25 & Cukup \\
\hline Kesesuaian dengan kaidah & 3,00 & 3,00 & 3,00 & Cukup \\
\hline
\end{tabular}




\begin{tabular}{|l|c|c|c|c|}
\hline bahasa & & & & \\
\hline $\begin{array}{l}\text { Penggunaan istilah, } \\
\text { simbol dan ikon }\end{array}$ & 2,75 & 3,00 & 2,88 & Cukup \\
\hline Rerata Total & 3,08 & 3,04 & $\mathbf{3 , 0 6}$ & Cukup \\
\hline
\end{tabular}

Tabel di atas menunjukkan hasil validasi kelayakan bahasa yang digunakan di dalam bahan ajar Kajian Apresiasi Prosa Fiksi berbasis kearifan lokal Makassar terintegrasi mobile learning. Sesuai dengan ketentuan yang ditetapkan oleh Badan Satandar Nasional Pendidikan (BSNP 2006) bahwa materi atau bahan ajar terstandar pada pemakain bahasa Indonesia ragam baku

Adapun hasil validasi bahan ajar tahap 2 setelah dilakukan perbaikan sebagai berikut: sesuai dengan PUEBI (Pedoman Umum Ejaan Bahasa Indonesia). Tabel di atas menunjukkan bahwa aspek kelugasan bahasa belum dinyatakan layak dengan rerata aspek sebesar 3,13 atau dengan kategori cukup layak.Rerata aspek komunikatif bahasa sebesar 3,25 atau dengan kategori cukup layak.

Tabel 9. Hasil Validasi Kebahasaan Bahan Ajar (Tahap 2)

\begin{tabular}{|l|c|c|c|c|}
\hline \multirow{2}{*}{ Aspek } & \multicolumn{2}{|c|}{ Rerata Validator } & Rerata & Keterangan \\
\cline { 2 - 3 } & I & II & Layak \\
\hline Lugas & 4,25 & 4,00 & 4,13 & Sangat Layak \\
\hline Komunikatif & 4,50 & 4,50 & 4,50 & Layak \\
\hline Dialogis dan interaktif & 3,75 & 4,00 & 3,88 & Sangat Layak \\
\hline $\begin{array}{l}\text { Kesesuaian dengan } \\
\text { perkembangan peserta didik }\end{array}$ & 4,50 & 4,00 & 4,25 & Layak \\
\hline $\begin{array}{l}\text { Kesesuaian dengan kaidah } \\
\text { bahasa }\end{array}$ & 3,50 & 4,50 & 4,00 & Sangat Layak \\
\hline $\begin{array}{l}\text { Penggunaan istilah, simbol } \\
\text { dan ikon }\end{array}$ & 4,75 & 4,00 & 4,38 & Layak \\
\hline Rerata Total & 4,21 & 4,17 & 4,19 & \\
\hline
\end{tabular}

Tabel di atas menunjukkan hasil validasi aspek kebahasaan bahan ajar tahap 2. Dari tabel tersebut, diketahui adanya peningkatan hasil penilaian kelayakan yang sangat signifikan dari kedua validator. Tidak dijumpai lagi aspek kebahasaan yang dinilai belum layak. Hanya saja, masih ada sebagian kecil yang luput dari pengamatan dan perhatian peneliti sehingga kedua

Tabel 10. Simpulan Respon Subjek Uji Coba

\begin{tabular}{|l|c|c|c|}
\hline \multicolumn{1}{|c|}{ Kelompok Uji Coba } & $\boldsymbol{\Sigma}$ Subjek & Rerata Total & Keterangan \\
\hline Preliminary Field Test & 6 & 3,75 & Baik \\
\hline Main Field Test & 12 & 4,38 & Sangat Baik \\
\hline
\end{tabular}




\begin{tabular}{|l|l|l|l|}
\hline Operational Field Test & 24 & 4,88 & Sangat Baik \\
\hline
\end{tabular}

Tabel di atas menunjukkan tingkat apresiasi atau respon mahasiswa subjek uji coba terhadap bahan ajar yang telah dikembangkan. Subjek uji coba satu-satu (Preliminary Field Test) yang berjumlah enam orang merespon bahan ajar dengan baik yaitu dengan rerata total sebesar 3,75. Subjek uji coba satu-satu menilai bahan ajar masih memiliki beberapa kelemahan khususnya pada aspek kualitas teknik penggunaan bahan ajar. Sesuai dengan hasil pengamatan peneliti saat uji coba, mahasiswa mengalami beberapa kendala untuk dapat menggunakan bahan ajar tersebut. misalnya, ditemukannya telepon berbasis android yang tidak compatible dengan perangkat bahan ajar. Dari hasil tersebut, peneliti menarik kesimpulan bahwa bahan ajar yang dikembangkan memiliki klasifikasi android yang dapat menggunakan yaitu memiliki storage yang besar, serta kualitas atau standar androidnya minimal KitKat atau Jellybean.

\section{Deskripsi Keterbacaan Bahan Ajar Kajian Apresiasi Prosa Fiksi Berbasis Kearifan Lokal Terintegrasi Mobile Learning Mahasiswa FKIP Universitas Muhammadiyah Makassar}

Uji keterbacaan bahan ajar dengan teknik Cloze Test (Prosedur Klos/isian rumpang) ini menggunakan 30 mahasiswa. Hasil uji keterbacaan tersebut dapat dilihat pada tabel berikut.

Tabel 11. Hasil uji keterbacaan dengan teknik Cloze Test

\begin{tabular}{|c|c|c|c|c|c|c|c|c|c|}
\hline \multirow{2}{*}{ No. } & \multirow{2}{*}{ Kode } & \multicolumn{6}{|c|}{ Wacana/Paragraf } & \multirow{2}{*}{$\begin{array}{c}\Sigma \text { Jawaban } \\
\text { Benar }\end{array}$} & \multirow{2}{*}{ Persentase } \\
\hline & & 1 & 2 & 3 & 4 & 5 & 6 & & \\
\hline 1 & SUK 001 & 9 & 8 & 8 & 8 & 7 & 8 & 48 & 80 \\
\hline 2 & SUK 002 & 8 & 8 & 9 & 9 & 8 & 8 & 50 & 83,33 \\
\hline 3 & SUK 003 & 10 & 9 & 8 & 8 & 8 & 8 & 51 & 85 \\
\hline 4 & SUK 004 & 9 & 8 & 9 & 9 & 8 & 8 & 51 & 85 \\
\hline 5 & SUK 005 & 8 & 8 & 8 & 8 & 9 & 8 & 49 & 81,67 \\
\hline 6 & SUK 006 & 8 & 5 & 8 & 6 & 6 & 8 & 41 & 68,33 \\
\hline 7 & SUK 007 & 9 & 8 & 8 & 8 & 8 & 7 & 48 & 80 \\
\hline 8 & SUK 008 & 9 & 8 & 8 & 8 & 9 & 8 & 50 & 83,33 \\
\hline 9 & SUK 009 & 8 & 8 & 9 & 9 & 8 & 7 & 49 & 81,67 \\
\hline 10 & SUK 010 & 10 & 9 & 8 & 9 & 9 & 9 & 54 & 90 \\
\hline 11 & SUK 011 & 9 & 8 & 9 & 9 & 8 & 8 & 51 & 85 \\
\hline 12 & SUK 012 & 10 & 9 & 8 & 8 & 8 & 8 & 51 & 85 \\
\hline 13 & SUK 013 & 9 & 9 & 8 & 9 & 9 & 8 & 52 & 86,67 \\
\hline 14 & SUK 014 & 9 & 9 & 8 & 8 & 9 & 7 & 50 & 83,33 \\
\hline 15 & SUK 015 & 10 & 9 & 8 & 9 & 9 & 8 & 53 & 88,33 \\
\hline 16 & SUK 016 & 8 & 8 & 8 & 8 & 8 & 8 & 48 & 80 \\
\hline 17 & SUK 017 & 10 & 9 & 8 & 9 & 7 & 8 & 51 & 85 \\
\hline 18 & SUK 018 & 8 & 8 & 8 & 8 & 8 & 9 & 49 & 81,67 \\
\hline 19 & SUK 019 & 7 & 8 & 7 & 9 & 9 & 8 & 48 & 80 \\
\hline 20 & SUK 020 & 7 & 8 & 6 & 8 & 8 & 8 & 45 & 75 \\
\hline 21 & SUK 021 & 6 & 8 & 7 & 7 & 9 & 8 & 45 & 75 \\
\hline 22 & SUK 022 & 6 & 7 & 8 & 8 & 8 & 7 & 44 & 73,33 \\
\hline
\end{tabular}




\begin{tabular}{|l|c|c|c|c|c|c|c|c|c|}
\hline 23 & SUK 023 & 6 & 8 & 7 & 9 & 8 & 8 & 46 & 76,67 \\
\hline 24 & SUK 024 & 7 & 7 & 7 & 8 & 8 & 8 & 45 & 75 \\
\hline 25 & SUK 025 & 9 & 7 & 7 & 8 & 9 & 8 & 48 & 80 \\
\hline 26 & SUK 026 & 8 & 8 & 7 & 9 & 9 & 8 & 49 & 81,67 \\
\hline 27 & SUK 027 & 9 & 8 & 8 & 7 & 8 & 7 & 47 & 78,33 \\
\hline 28 & SUK 028 & 9 & 9 & 8 & 8 & 8 & 8 & 50 & 83,33 \\
\hline 29 & SUK 029 & 10 & 9 & 8 & 8 & 8 & 8 & 51 & 85 \\
\hline 30 & SUK 030 & 10 & 9 & 8 & 8 & 9 & 8 & 52 & 86,67 \\
\hline \multicolumn{8}{|c|}{ Rata-rata } \\
\hline
\end{tabular}

Tabel diatas memperlihatkan bahwa keseluruhan mahasiswa mampu mengisi teks atau wacana yang dirumpangkan dengan baik. Hal ini dibuktikan dengan persentase jawaban benar setiap mahasiswa > 60\%. Selanjutnya, rerata total persentase jawaban benar mahasiswa sebesar $81,45 \%$ lebih besar dari $60 \%(81,45>60)$ sehingga bahan ajar dinyatakan mudah dibaca dan dipahami oleh mahasiswa.
2. Deskripsi Kepraktisan Bahan Ajar Kajian Apresiasi Prosa Fiksi Berbasis Kearifan Lokal Terintegrasi Mobile Learning Mahasiswa FKIP Universitas Muhammadiyah Makassar

Data pengolaan bahan ajar dikumpulkan melalui kegiatan observasi (format angket) yang dilakukan langsung oleh peneliti selama tindakan penerapan bahan ajar di lakukan. Adapun hasil penilaian pengolaan bahan ajar dalam pembelajaran seperti pada tabel berikut:

Tabel 12. Pengelolaan Bahan ajar Kelas Implementasi 1

\begin{tabular}{|c|l|c|c|}
\hline No. & \multicolumn{1}{|c|}{ Aspek } & Rerata Aspek & Keterangan \\
\hline 1 & Kemudahan pemakaian & 4,00 & Praktis \\
\hline 2 & Keterkaitan bahan ajar dengan kegiatan belajar & 4,00 & Praktis \\
\hline 3 & Bahan ajar sebagai sumber belajar utama & 4,50 & Sangat Praktis \\
\hline 4 & Bahan ajar sebagai sumber tugas atau latihan & 4,50 & Sangat Praktis \\
\hline 5 & Bahan ajar sebagai sumber konsep nilai-nilai & 4,00 & Praktis \\
\hline \multicolumn{2}{|l|}{ Rerata Total } & $\mathbf{4 , 2 0}$ & Sangat Praktis \\
\hline
\end{tabular}

Tabel di atas menunjukkan hasil observasi peneliti terhadap pengelolaan bahan ajar di dalam kegiatan belajar pada kelas implementasi 1. Tabel di atas membuktikan bahwa bahan ajar yang dikembangkan parktis digunakan jika ditinjau dari cara mahasiswa dan dosen model melibatkan bahan ajar tersebut di dalam kegiatan belajar. Pertama, bahan ajar mudah dipakai dengan rerata aspek sebesar 4,00 atau dengan kategori praktis. Kedua, bahan ajar terkait dengan kegiatan belajar. Artinya, kegiatan belajar mengacu pada langkah-langkah pembelajaran untuk mencapai tujuan pembelajaran. Rerata aspek kedua sebesar 4,00 atau dengan kategori praktis. Aspek ketiga yaitu bahan ajar sebagai sumber utama artinya bahan ajar ini dijadikan sebagai bahan ajar pokok (bukan suplemen) sehingga secara keseluruhan rangkaian belajar bersumber dari bahan ajar tersebut. rerata aspek ketiga yaitu 4,50 atau dengan kategori sangat praktis. Aspek ke empat yaitu bahan ajar sebagai sumber tugas atau latihan dengan rerata aspek sebesar 4,50 atau dengan kategori sangat baik karena setiap kegiatan belajar dalam bahan ajar disertai dengan tugas dan latihan. Terakhir, 
sesuai dengan namanya, bahan ajar ini diintegrasikan dengan nilai kearifan lokal Makassar. Oleh karena itu, sumber nilai dalam pembelajaran adalah bahan ajar. Rerata aspek ini sebesar 4,00 atau dengan kategori praktis. Secara keseluruhan, pengelolaan bahan ajar di kelas implementasi 1 dikategorikan sangat praktis dengan rerata total sebesar 4,20.

Tabel 13.Pengelolaan Bahan ajar Kelas Implementasi 2

\begin{tabular}{|c|l|c|c|}
\hline No. & \multicolumn{1}{|c|}{ Aspek } & Rerata Aspek & Keterangan \\
\hline 1 & Kemudahan pemakaian & 4,50 & Sangat Praktis \\
\hline 2 & $\begin{array}{l}\text { Keterkaitan bahan ajar dengan } \\
\text { kegiatan belajar }\end{array}$ & 4,50 & Sangat Praktis \\
\hline 3 & $\begin{array}{l}\text { Bahan ajar sebagai sumber belajar } \\
\text { utama }\end{array}$ & 5,00 & Sangat Praktis \\
\hline 4 & $\begin{array}{l}\text { Bahan ajar sebagai sumber tugas atau } \\
\text { latihan }\end{array}$ & 5,00 & Praktis \\
\hline 5 & $\begin{array}{l}\text { Bahan ajar sebagai sumber konsep } \\
\text { nilai-nilai }\end{array}$ & 4,00 & Sangat Baik \\
\hline Rerata Total
\end{tabular}

Tabel di atas menunjukkan hasil penilaian pengelolaan bahan ajar di dalam kegiatan belajar kelas implementasi 2 . Aspek kemudahan pemakaian dinilai sangat praktis dengan rerata 4,50. Artinya, mahasiswa sebagai pemakai bahan ajar mudah untuk menggunakannya. Aspek keterkaitan bahan ajar dengan kegiatan belajar juga dinilai sangat praktis karena dosen model mengembangkan pembelajaran dengan mengacu pada bahan ajar (tujuan dan indikator yang ingin dicapai) dengan rerata aspek sebesar 4,50 atau dengan kategori sangat praktis. Selanjutnya, dua aspek pengelolaan pembelajaran meliputi aspek bahan ajar sebagai sumber belajar utama dan asepk bahan ajar sebagai sumber tugas atau latihan dinilai sangat praktis dengan rerata aspek masing-masing 5,00. Sedangkan aspek kelima yaitu bahan ajar sebagai sumber ilmu sebesar 4,00 atau dengan kategori praktis. Sebab, dosen model juga terlibat sebagai sumber nilai melalui sikap dosen model dan penjelasan verbal mengenai nilai-nilai yang terdapat di dalam bahan ajar.

Tabel 14.Pengelolaan Bahan ajar Kelas Implementasi 3

\begin{tabular}{|c|l|c|c|}
\hline No. & \multicolumn{1}{|c|}{ Aspek } & Rerata Aspek & Keterangan \\
\hline 1 & Kemudahan pemakaian & 4,50 & Sangat Praktis \\
\hline 2 & $\begin{array}{l}\text { Keterkaitan bahan ajar dengan } \\
\text { kegiatan belajar }\end{array}$ & 4,50 & Sangat Praktis \\
\hline 3 & $\begin{array}{l}\text { Bahan ajar sebagai sumber belajar } \\
\text { utama }\end{array}$ & 5,00 & Sangat Praktis \\
\hline 4 & $\begin{array}{l}\text { Bahan ajar sebagai sumber tugas atau } \\
\text { latihan }\end{array}$ & 5,00 & Sangat Praktis \\
\hline 5 & $\begin{array}{l}\text { Bahan ajar sebagai sumber konsep } \\
\text { nilai-nilai }\end{array}$ & 4,50 & Sangat Praktis \\
\hline Rerata Total & $\mathbf{4 , 7 0}$ & \\
\hline
\end{tabular}

Tabel atas menunjukkan hasil penilaian pengelolaan bahan ajar di dalam kegiatan belajar kelas implementasi 3. Pada hakikatnya, hasil penilaian kelas 
implementasi 3 serupa dengan kelas implementasi lainnya di mana semua aspek dinilai praktis atau sangat praktis. Bahkan, hasil penilaian di kelas implementasi 3 cenderung lebih baik dari kelas implementasi lainnya. Secara keseluruhan, bahan ajar dinyatakan praktis dengan rerata total sebesar 4,70 atau dengan kategori sangat praktis.

\section{Deskripsi Keefektifan Bahan Ajar} Kajian Apresiasi Prosa Fiksi Berbasis
Kearifan Lokal Terintegrasi Mobile Learning Mahasiswa FKIP Universitas Muhammadiyah Makassar

Adapun hasil ketuntasan belajar mahasiswa sebelum (pretest) dan setelah (posttest) pembelajaran menggunakan bahan ajar Kajian Apresiasi Prosa Fiksi berbasis kearifan lokal Makassar terintegrasi mobile learning ditunjukkan dalam tabel berikut:

Tabel 15 Ketuntasan Belajar Pretest

\begin{tabular}{|c|c|c|c|c|c|c|c|c|c|c|c|}
\hline $\mathbf{S}$ & $\boldsymbol{P r e}$ & Ket. & $\mathbf{S}$ & $\boldsymbol{P r} \boldsymbol{K}$ & Ket. & $\mathbf{S}$ & $\boldsymbol{P r e}$ & Ket. & $\mathbf{S}$ & Pre & Ket. \\
\hline 1 & 26 & TT & 26 & 16 & TT & 51 & 43 & T & 76 & 21 & TT \\
\hline 2 & 19 & TT & 27 & 18 & TT & 52 & 23 & TT & 77 & 47 & T \\
\hline 3 & 44 & T & 28 & 45 & T & 53 & 42 & T & 78 & 32 & TT \\
\hline 4 & 31 & TT & 29 & 32 & TT & 54 & 44 & T & 79 & 36 & TT \\
\hline 5 & 25 & TT & 30 & 36 & TT & 55 & 40 & TT & 80 & 40 & TT \\
\hline 6 & 27 & TT & 31 & 40 & TT & 56 & 41 & TT & 81 & 27 & TT \\
\hline 7 & 21 & TT & 32 & 27 & TT & 57 & 23 & TT & 82 & 42 & T \\
\hline 8 & 42 & T & 33 & 28 & TT & 58 & 36 & TT & 83 & 24 & TT \\
\hline 9 & 42 & T & 34 & 31 & TT & 59 & 27 & TT & 84 & 34 & TT \\
\hline 10 & 28 & TT & 35 & 51 & T & 60 & 45 & T & 85 & 26 & TT \\
\hline 11 & 23 & TT & 36 & 23 & TT & 61 & 18 & TT & 86 & 17 & TT \\
\hline 12 & 31 & TT & 37 & 41 & TT & 62 & 32 & TT & 87 & 40 & TT \\
\hline 13 & 24 & TT & 38 & 40 & TT & 63 & 24 & TT & 88 & 45 & T \\
\hline 14 & 26 & TT & 39 & 48 & T & 64 & 46 & T & 89 & 23 & TT \\
\hline 15 & 34 & TT & 40 & 32 & TT & 65 & 19 & TT & 90 & 31 & TT \\
\hline 16 & 42 & T & 41 & 45 & T & 66 & 14 & TT & 91 & 24 & TT \\
\hline 17 & 16 & TT & 42 & 23 & TT & 67 & 24 & TT & 91 & 47 & T \\
\hline 18 & 22 & TT & 43 & 23 & TT & 68 & 34 & TT & 93 & 19 & TT \\
\hline 19 & 26 & TT & 44 & 18 & TT & 69 & 26 & TT & 94 & 21 & TT \\
\hline 20 & 46 & T & 45 & 44 & T & 70 & 17 & TT & 95 & 47 & T \\
\hline 21 & 27 & TT & 46 & 19 & TT & 71 & 40 & TT & 96 & 23 & TT \\
\hline
\end{tabular}




\begin{tabular}{|c|c|c|c|c|c|c|c|c|c|c|c|}
\hline 22 & 34 & TT & 47 & 21 & TT & 72 & 43 & T & 97 & 31 & TT \\
\hline 23 & 28 & TT & 48 & 29 & TT & 73 & 23 & TT & 98 & 24 & TT \\
\hline 24 & 43 & T & 49 & 35 & TT & 74 & 25 & TT & 99 & 26 & TT \\
\hline 25 & 34 & TT & 50 & 37 & TT & 75 & 35 & TT & 100 & 34 & TT \\
\hline
\end{tabular}

Ket. S (Subjek), Pre (Skor), T (Tuntas), TT (Tidak Tuntas),

Subjek yang dinyatakan tuntas

Tabel di atas menunjukkan hasil tes kemampuan awal mahasiswa yang dijadikan sebagai acuan dasar untuk menentukan ketuntasan belajar mahasiswa. Dinyatakan tuntas jika mahasiswa mampu menjawab soal dengan benar sebanyak 42 (minimal) sampai dengan 60 (maksimal). Nilai yang diperoleh jika jawaban benar adalah satu.
Jadi jika jawaban mahasiswa benar 42 maka nilai akhir yang diperoleh adalah 70 dan dinyatakan tuntas sesuai KKB. Cara menentukan nilai menggunakan rumus penentuan nilai akhir yaitu jumlah skor perolehan dibagikan dengan skor maksimal (60) dikalikan dengan 100.

Tabel 16. Ketuntasan Belajar Posttest

\begin{tabular}{|c|c|c|c|c|c|c|c|c|c|c|c|}
\hline S & Pre & Ket. & S & Pre & Ket. & S & Pre & Ket. & S & Pre & Ket. \\
\hline 1 & 45 & $\mathrm{~T}$ & 26 & 35 & $\mathrm{TT}$ & 51 & 56 & $\mathrm{~T}$ & 76 & 38 & $\mathrm{TT}$ \\
\hline 2 & 37 & $\mathrm{TT}$ & 27 & 32 & $\mathrm{TT}$ & 52 & 43 & $\mathrm{~T}$ & 77 & 51 & $\mathrm{~T}$ \\
\hline 3 & 53 & $\mathrm{~T}$ & 28 & 54 & $\mathrm{~T}$ & 53 & 57 & $\mathrm{~T}$ & 78 & 47 & $\mathrm{~T}$ \\
\hline 4 & 47 & $\mathrm{~T}$ & 29 & 45 & $\mathrm{~T}$ & 54 & 58 & $\mathrm{~T}$ & 79 & 43 & $\mathrm{~T}$ \\
\hline 5 & 57 & $\mathrm{~T}$ & 30 & 48 & $\mathrm{~T}$ & 55 & 54 & $\mathrm{~T}$ & 80 & 51 & $\mathrm{~T}$ \\
\hline 6 & 38 & $\mathrm{TT}$ & 31 & 57 & $\mathrm{~T}$ & 56 & 52 & $\mathrm{~T}$ & 81 & 37 & $\mathrm{TT}$ \\
\hline 7 & 40 & $\mathrm{TT}$ & 32 & 39 & $\mathrm{TT}$ & 57 & 43 & $\mathrm{~T}$ & 82 & 54 & $\mathrm{~T}$ \\
\hline 8 & 58 & $\mathrm{~T}$ & 33 & 42 & $\mathrm{~T}$ & 58 & 46 & $\mathrm{~T}$ & 83 & 37 & $\mathrm{TT}$ \\
\hline 9 & 54 & $\mathrm{~T}$ & 34 & 56 & $\mathrm{~T}$ & 59 & 40 & $\mathrm{TT}$ & 84 & 48 & $\mathrm{~T}$ \\
\hline 10 & 44 & $\mathrm{~T}$ & 35 & 60 & $\mathrm{~T}$ & 60 & 58 & $\mathrm{~T}$ & 85 & 42 & $\mathrm{~T}$ \\
\hline 11 & 43 & $\mathrm{~T}$ & 36 & 43 & $\mathrm{~T}$ & 61 & 32 & $\mathrm{TT}$ & 86 & 26 & $\mathrm{TT}$ \\
\hline 12 & 51 & $\mathrm{~T}$ & 37 & 54 & $\mathrm{~T}$ & 62 & 45 & $\mathrm{~T}$ & 87 & 52 & $\mathrm{~T}$ \\
\hline 13 & 46 & $\mathrm{~T}$ & 38 & 54 & $\mathrm{~T}$ & 63 & 42 & $\mathrm{~T}$ & 88 & 54 & $\mathrm{~T}$ \\
\hline 14 & 42 & $\mathrm{~T}$ & 39 & 59 & $\mathrm{~T}$ & 64 & 58 & $\mathrm{~T}$ & 89 & 42 & $\mathrm{~T}$ \\
\hline 15 & 46 & $\mathrm{~T}$ & 40 & 45 & $\mathrm{~T}$ & 65 & 26 & $\mathrm{TT}$ & 90 & 45 & $\mathrm{~T}$ \\
\hline 16 & 57 & $\mathrm{~T}$ & 41 & 57 & $\mathrm{~T}$ & 66 & 23 & $\mathrm{TT}$ & 91 & 42 & $\mathrm{~T}$ \\
\hline
\end{tabular}




\begin{tabular}{|c|c|c|c|c|c|c|c|c|c|c|c|}
\hline 17 & 31 & $\mathrm{TT}$ & 42 & 43 & $\mathrm{~T}$ & 67 & 45 & $\mathrm{~T}$ & 91 & 56 & $\mathrm{~T}$ \\
\hline 18 & 38 & $\mathrm{TT}$ & 43 & 41 & $\mathrm{TT}$ & 68 & 51 & $\mathrm{~T}$ & 93 & 32 & $\mathrm{TT}$ \\
\hline 19 & 42 & $\mathrm{~T}$ & 44 & 32 & $\mathrm{TT}$ & 69 & 43 & $\mathrm{~T}$ & 94 & 41 & $\mathrm{TT}$ \\
\hline 20 & 58 & $\mathrm{~T}$ & 45 & 51 & $\mathrm{~T}$ & 70 & 25 & $\mathrm{~T}$ & 95 & 56 & $\mathrm{~T}$ \\
\hline 21 & 43 & $\mathrm{~T}$ & 46 & 34 & $\mathrm{TT}$ & 71 & 56 & $\mathrm{~T}$ & 96 & 41 & $\mathrm{TT}$ \\
\hline 22 & 48 & $\mathrm{~T}$ & 47 & 44 & $\mathrm{~T}$ & 72 & 57 & $\mathrm{~T}$ & 97 & 51 & $\mathrm{~T}$ \\
\hline 23 & 41 & $\mathrm{TT}$ & 48 & 43 & $\mathrm{~T}$ & 73 & 41 & $\mathrm{TT}$ & 98 & 42 & $\mathrm{~T}$ \\
\hline 24 & 56 & $\mathrm{~T}$ & 49 & 54 & $\mathrm{~T}$ & 74 & 45 & $\mathrm{~T}$ & 99 & 45 & $\mathrm{~T}$ \\
\hline 25 & 47 & $\mathrm{~T}$ & 50 & 52 & $\mathrm{~T}$ & 75 & 48 & $\mathrm{~T}$ & 100 & 49 & $\mathrm{~T}$ \\
\hline
\end{tabular}

Ket. S (Subjek), Pre (Skor), T (Tuntas), TT (Tidak Tuntas),

Subjek yang dinyatakan tidak tuntas

Tabel di atas menunjukkan hasil tes kemampuan mahasiswa setelah melakukan kegiatan pembelajaran dengan menggunakan bahan ajar Kajian Apresiasi Prosa Fiksi yang dikembangkan. Jika pada tes kemampuan awal nilai terendah yang diraih mahasiswa adalah 14 atau dengan nilai 23 (subjek 66), maka tes kemampuan akhir subjek 23 mengalami peningkatan yang signifikan menjadi 41 jawaban benar atau dengan nilai
68. Namun, nilai tersebut belum dinyatakan tuntas. Tetapi paling tidak ada peningkatan sebesar $27 \%$.

Berdasarkan hasil observasi, diketahui bahwa mahasiswa mampu memahami dan mengamalkan nilai-nilai kearifan lokal Makassar tersebut selama pembelajaran berlangsung. Hasil tersebut ditampilkan dalam tabel berikut:

Tabel 17. Deskripsi Implementasi Nilai Kearifan Lokal di dalam Pembelajaran

\begin{tabular}{|c|c|c|}
\hline Aktivitas Belajar & Implementasi Nilai & Persentase \\
\hline $\begin{array}{l}\text { 1. Mahasiwa mengawali dan menutup } \\
\text { kegiatan belajar dengan berdoa dan } \\
\text { memberikan salam }\end{array}$ & $\begin{array}{l}\text { Nilai keimanan dan } \\
\text { ketaqwaan }\end{array}$ & $100 \%$ \\
\hline $\begin{array}{l}\text { 2. Setiap pembicaraan (bertanya atau } \\
\text { menjawab) selalu diawali dengan } \\
\text { bismillah dan salam) }\end{array}$ & $\begin{array}{l}\text { Nilai keimanan dan } \\
\text { ketaqwaan }\end{array}$ & $100 \%$ \\
\hline $\begin{array}{l}\text { 3. Mahasiswa dengan jujur mengakui } \\
\text { ketidakpahaman mereka tentang materi } \\
\text { atau jujur dalam mengerjakan tugas }\end{array}$ & Nilai kejujuran & $100 \%$ \\
\hline $\begin{array}{l}\text { 4. Mahasiswa mengkuit kegiatan belajar } \\
\text { secara seksama, mengamati dan } \\
\text { mempelajari materi dengan tekun, } \\
\text { mengerjakan tugas dengan baik, dan } \\
\text { berani mengkritik jika terjadi kesalahan. }\end{array}$ & Nilai kecendekiaan & $100 \%$ \\
\hline
\end{tabular}




\begin{tabular}{|c|c|c|c|}
\hline & $\begin{array}{l}\text { Secara mandiri dan/atau berkelompok } \\
\text { mahasiswa berusaha untuk menjawab } \\
\text { tantangan dari dosen atau mengerjakan } \\
\text { tugas dengan baik. }\end{array}$ & $\begin{array}{l}\text { Nilai keteguhan dan kerja } \\
\text { keras }\end{array}$ & $100 \%$ \\
\hline 6. & $\begin{array}{l}\text { Mahasiswa selalu menaati nasihat atau } \\
\text { teguran dari dosen model terkait tata } \\
\text { tertib yang disepakati. Sebagai contoh } \\
\text { busana yang digunakan harus berada } \\
\text { pada zona kesopanan dan etika } \\
\text { berbusana seorang muslim dan } \\
\text { muslimah. }\end{array}$ & Nilai kedisiplinan & $100 \%$ \\
\hline 7. & $\begin{array}{l}\text { Setelah melakukan kesalahan dan } \\
\text { mendapatkan teguran atau sanksi dari } \\
\text { dosen, maka mahasiswa tidak } \\
\text { melakukan hal yang sama untuk yang } \\
\text { kedua, ketiga, atau kesekian kalinya. }\end{array}$ & Nilai harga diri (siri') & $100 \%$ \\
\hline
\end{tabular}

\section{KESIMPULAN}

Berdasarkan deskripsi kelayakan, keterbacaan, kepraktisan, dan keefektifan, bahan ajar , maka penelitian ini dapat disimpulan sebagai berikut.

Bahan ajar Kajian Apresiasi prosa Fiksi berbasis kearifan lokal Makassar layak digunakan karena telah teruji kelayakannya melalui uji pakar dan uji coba. Rerata unsur materi sebesar 4,32 atau dengan kategori sangat layak, rerata unsur penyajian 4,07 atau dengan kategori layak, rerata aspek kegrafikan sebesar 4,33 atau dengan kategori sangat layak, rerata aspek kebahasaan sebesar 4,19 atau dengan kategori layak, dan terakhir aspek media atau teknologi dengan rerata total sebesar 4,19 dengan kategori layak. Penilaian kelayakan juga bersumber dari mahasiswa subjek uji coba. Rerata penilaian subjek uji coba satu-satu yang berjumlah enam mahasiswa adalah 3,75 atau dengan kategori layak, rerata penilaian kelayakan subjek uji coba lapangan utama yaitu 4,38 dengan kategori sangat layak, dan rerata penilaian kelayakan subjek uji coba lapangan operasional yaitu 4,38 dengan kategori sangat layak.
Bahan ajar Kajian Apresiasi prosa Fiksi berbasis kearifan lokal Makassar layak digunakan karena memiliki tingkat keterbacaan yang tinggi yaitu dengan persentase skor tes uji rumpang sebesar $81,45 \%$. Artinya bahan ajar mudah dibaca oleh mahasiswa sehingga pesan atau isi yang terdapat di dalam bahan ajar mudah dipahami oleh mahasiswa.

Bahan ajar Kajian Apresiasi prosa Fiksi berbasis kearifan lokal Makassar layak digunakan karena praktis dalam penggunaannya. Hasil penilaian keterlaksanaan bahan ajar membuktikan bahwa pembelajaran yang menggunakan bahan ajar tersebut terlaksana dengan sangat baik di mana rerata evaluasi program pembelajaran kelas implementasi 1 sebesar 4,25 atau dengan kategori sangat layak, kelas implementasi 2 sebesar 4,40 atau dengan kategori sangat layak, dan kelas implementasi 3 sebesar 4,60 atau dengan kategori sangat layak. Selanjutnya, pengelolaan pemakaian bahan ajar di dalam pembelajaran menunjukkan hasil yang sangat baik. Bahan ajar diimplementasikan secara maksimal di mana rerata kelas implementasi 1 sebesar 4,20 atau dengan kategori sangat praktis, kelas implementasi 2 sebesar 4,60 atau dengan kategori sangat 
praktis, dan kelas implementasi 3 sebesar 4,50 atau dengan kategori sangat praktis.

Bahan ajar Kajian Apresiasi prosa Fiksi berbasis kearifan lokal Makassar layak digunakan karena efektif terhadap peningkatan hasil belajar mahasiswa dan pemahaman nilai-nilai kearifan lokal Makassar. Hasil tes membuktikan bahwa terjadi peningkatan ketuntasan belajar mahasiswa. Hasil tes kemampuan awal hanya $22 \%$ mahasiswa yang dinyatakan tuntas sedangkan hasil tes kemampuan akhir sebanyak $76 \%$. Selanjutnya, hasil tes pemahaman nilai-nilai kearifan budaya lokal Makassar membuktikan bahwa $91 \%$ mahasiswa mampu menemukan nilai-nilai kearifan lokal tersebut dan menjabarkannya berdasarkan realitas yang ada.

\section{DAFTAR PUSTAKA}

Abrams, M.H. 1981. A Glossary of Literary Teams. Holt. Rinehart and Winston

New York.

Akib, I. 2007. Model Pembelajaran Matematika Berbasis Budaya Bugis Makassar. Disertasi. Surabaya. Universitas Negeri Surabaya.

Akker, J. V. D. 1999. Principles and Method of Development Research. London. Dlm.

Aminuddin. 2011. Pengantar Apresiasi Karya Sastra. Bandung: Sinar Baru Algensindo.

Batari, U. T. 2014. Pengembangan Bahan Ajar Bahasa Indonesia Berbasis Cerita Rakyat Siswa Kelas III di Kabupaten Gowa. Disertasi. Tidak diterbitkan. Makassar: Program Pascasarjana UNM Makassar.

Departemen Pendidikan Nasional. 2006. Panduan Pengembangan Bahan Ajar. Jakarta: Direktorat Pendidikan Dasar Menengah.

Emzir \& Rahman, S. 2015. Teori dan Pengajaran Sastra. Jakarta: Raja Grafindo Persada.
Gagne. 1984. Kondisi Belajar dan Teori Pembelajaran. Terjemahan Munandir 1989. Jakarta: Depdikbud Dirjen Pendidikan Tinggi.

Joyoatmojo, S. 2003. Pembelajaran Efektif: Upaya PeningkatanKualitas Lulusan Menuju Penyediaan sumber Daya Insani yang Unggul. Pidato Pengukuhan Guru Besar Fakultas Keguruan dan Ilmu pendidikanUniversitas Sebelas Maret Surakarta pada tanggal 24 Mei 2003. Diakses di digilib.uns.ac.id. pada 17 Juli 2016.

Nieveen, N.1999. Prototyping to Reach Product Quality. In J. vam den Akker,R Branch,K Gustafson, N Nieveen and Tj.Plomp (Eds). Design Approaches and Tools in Education and Training (hlm. 125-136). Dodrecht : Kluwer Academic Publisher.

Prastowo. 2013. Panduan Kreatif Membuat Bahan Ajar Innovatif. Yogyakarta: DIVA Press.

Setyosari. 2013. Metode Penelitian Pendidikan dan Pengembangan. Jakarta: Kencana Prenada Media Group.

Siswanto, W. 2008. Pengantar Teori Sastra. Jakarta : Grasindo

Sugiyono. 2013. Metode Penelitian Pendidikan Pendekatan Kuantitatif, Kualitatif, dan R\&D. Bandung: Alfabeta.

Sumarjdo, J \& Saini K.M. 1994. Apresiasi kesusastraan. Jakarta: Gramedia Pustaka.

Vavoula \& Sharples. 2009. Towards a Theory of Mobile Learning," Proceedings of M-Learn. Vol. 01, no. 01, pp. 1-9.

Wellek,R \& Warren, A. 2014. Teori Kesusastraan (Terjemahan Melanie Budianta). Jakarta: PT Gramedia Pustaka Utama.

Wiryokusumo, I. 2007. Dasar-Dasar Pengembangan Kurikulum. Jakarta: Bumi Aksara. 